\title{
The effect of blue and pink lotus flower extract on acne vulgaris: A randomized double-blind clinical trial
}

\section{Anna Gordon}

January, 2021

\begin{abstract}
:
Background:

Acne vulgaris is one of the leading ubiquitous diseases around the world. It is a multifactorial disease which does not threaten life but has serious psychological effects on patients. Patients with moderate to severe acne have been suggested to have poor body image, poor self-esteem, and social isolation and activity constraints. Increased levels of anxiety, anger, depression and frustration are also observed in patients with acne as part of the emotional impact.
\end{abstract}

\section{Research gap:}

More research on anti-acne treatments is necessary for two reasons. First, the prevalence of acne incidence is high and the effect on the quality of life is profound. Second, there is, according to the numerous studies, a lack of ant-acne treatments that have less side effect. The use of medicinal plants and particularly blue and pink lotus flower extract, with its autoinflammatory effect, could be promising. The blue and pink lotus flower extract is suggested to reduces the activity of sebum overproduction and helps to balance sebum secretion.

\section{Objective:}

The objective of this study was to examine the medical efficacy of blue and pink lotus flower extract in acne vulgaris.

\section{Method:}


In a randomized double-blind controlled clinical trial, 42 patients ( 21 patients in treatment and 21 in placebo group) were randomly received 'Nymphaea Caerulea Flower Extract, Nelumbo Nucifera Flower" and placebo extract, twice daily for 1 month. We recorded he Investigator's Global Assessment (IGA) grading score for each participant. In addition, we evaluated the Acne disability index (ADI) utilizing a standard questionnaire filled out by the participants at the beginning and at the end of the study.

\section{Results:}

The results indicated a $76 \%$ mean reduction in the IGA score on the treated group. The mean reduction in the vehicle-treated group, on the other hand, was $4.2 \%$. We also found that the number of comedones, papules, and pustules significantly reduced in the treatment group after 30 days. Additionally, the Acne disability index (ADI) score decreased by 65.01 percent in treatment group, and only 5.6 percent in the placebo group. The current study could not discover any significant side effect in both groups.

\section{Conclusion:}

The blue and pink lotus flower extract had significant effects on improving the symptoms of acne vulgaris. The results of this study, because of the small sample size, should however be interpreted with caution. The future study on the medical efficacy of the mentioned extract should examine with larger samples.

Keywords: acne vulgaris, lotus flower extract, Nelupure, Sebum.

Working paper series $S A$ med Press

\section{In-text citations:}

$[1][2][3][4][5][6][7][8][5][9][10][11][12][13][14][15][16]$ [17] [18] [15][2][19][20][21][22][23][24]

[24][25][26][27][28][29][30][31][32][33][34][35] [14] [36][37] [38] [37][39][39][40][41][42][43][44] [45] [46] [46] [47] [48] [49]

\section{Anna Gordon}

Anna Gordŭn e nauchen sŭtrudnik po fiziologiya - Fakultet po meditsinski i zdravni nauki, Universitet v Netam, Prilozhni nauki Bŭlgariya. 


\section{References}

[1] G. F. Graham and S. M. Tuchayi, "Acne," in Dermatological Cryosurgery and Cryotherapy, 2016.

[2] P. Jarrett, "Acne vulgaris," in Encyclopedia of Pharmacy Practice and Clinical Pharmacy, 2019.

[3] H. C. Williams, R. P. Dellavalle, and S. Garner, "Acne vulgaris," in The Lancet, 2012.

[4] K. Bhate and H. C. Williams, "Epidemiology of acne vulgaris," British Journal of Dermatology. 2013.

[5] A. L. Zaenglein et al., "Guidelines of care for the management of acne vulgaris," J. Am. Acad. Dermatol., 2016.

[6] S. Moradi Tuchayi, E. Makrantonaki, R. Ganceviciene, C. Dessinioti, S. R. Feldman, and C. C. Zouboulis, "Acne vulgaris," Nature reviews. Disease primers. 2015.

[7] S. E. Garner, A. Eady, C. Bennett, J. N. Newton, K. Thomas, and C. M. Popescu, "Minocycline for acne vulgaris: Efficacy and safety," Cochrane Database of Systematic Reviews. 2012.

[8] H. Cao et al., "Complementary therapies for acne vulgaris," Cochrane Database of Systematic Reviews. 2015.

[9] M. Tengiz, "APPLICATION OF GAME THEORYSIMULATION IN ENTERPRISE MANAGEMENT," in Colloquium-journal, 2020, no. 8 (60).

[10] R. Sanghvi and A. Gordon, "The plant-based-diet and obesity: The process and literature survey," 2021.

[11] T. Magradze, "MATHEMATICALMO DELING IN THE ENTERPRISE MANAGEMENT," in Colloquium-journal, 2020, no. 7 (59).

[12] T. Magradze, "TAX ADMINISTRATION IN THE RUSSIAN FEDERATION: CURRENT PROBLEMS AND DEVELOPMENT PROSPECTS," in Colloquium-journal, 2020, no. 5 (57).

[13] M. Tengiz, "NEW METHOdOLOGYOF EVALUATING THE EFFICIENCY OF MANAGERIAL DECISION-MAKING," in Colloquium-journal, 2020, no. 8 (60).

[14] J. K. L. Tan and K. Bhate, "A global perspective on the epidemiology of acne," British Journal of Dermatology. 2015.

[15] J. Burris, W. Rietkerk, and K. Woolf, "Acne: The Role of Medical Nutrition Therapy," J. Acad. Nutr. Diet., 2013.

[16] D. JAPARIDZE and T. MAGRADZE, "OPTIMAL PLANNING OF OPERATIVERESERVE OF ACTIVE POWER IN POWER SYSTEM UNDER CONDITIONS OF UNCERTAINTY."

[17] J. M. P. Pérez and M. C. De Hoyos López, “Acné,” Pediatr. Integr., 2012.

[18] C. A. Adebamowo et al., "Milk consumption and acne in teenaged boys," J. Am. Acad. Dermatol., 2008.

[19] R. N. Afriyanti, “Akne Vulgaris Pada Remaja,” Med. Fac. Lampung Univ., 2015.

[20] A. M. O'Neill and R. L. Gallo, "Host-microbiome interactions and recent progress into understanding the biology of acne vulgaris," Microbiome. 2018.

[21] W. P. Bowe and A. C. Logan, "Acne vulgaris, probiotics and the gut-brain-skin axis - Back to 
the future?," Gut Pathogens. 2011.

[22] R. Nguyen and J. Su, "Treatment of acne vulgaris," Paediatrics and Child Health. 2011.

[23] Grupo Colombiano de Estudio en Acné, “Guías colombianas para el manejo del acné: una revisión basada en la evidencia por el Grupo Colombiano de Estudio en Acné," Rev Asoc Colomb Dermatol, 2011.

[24] J. Revuz, "Diet and acne," Ann. Dermatol. Venereol., 2010.

[25] D. Kang, B. Shi, M. C. Erfe, N. Craft, and H. Li, "Vitamin B12 modulates the transcriptome of the skin microbiota in acne pathogenesis," Sci. Transl. Med., 2015.

[26] D. C. Liao, "Management of acne," Journal of Family Practice. 2003.

[27] W. P. Bowe, N. B. Patel, and A. C. Logan, "Acne vulgaris, probiotics and the gut-brain-skin axis: From anecdote to translational medicine," Beneficial Microbes. 2014.

[28] R. Ramli, A. S. Malik, A. F. M. Hani, and A. Jamil, "Acne analysis, grading and computational assessment methods: An overview," Skin Research and Technology. 2012.

[29] B. C. Melnik, "Acne vulgaris: The metabolic syndrome of the pilosebaceous follicle," Clin. Dermatol., 2018.

[30] E. Platsidaki and C. Dessinioti, "Recent advances in understanding Propionibacterium acnes (Cutibacterium acnes) in acne [version 1; referees: 2 approved]," F1000Research. 2018.

[31] A. R. Shalita, J. Q. Del Rosso, and G. F. Webster, Acne vulgaris. 2011.

[32] A. Layton, "The use of isotretinoin in acne," Dermatoendocrinol., 2009.

[33] S. Z. Ghodsi, H. Orawa, and C. C. Zouboulis, "Prevalence, severity, and severity risk factors of acne in high school pupils: A community-based study," J. Invest. Dermatol., 2009.

[34] D. Lynn, T. Umari, R. Dellavalle, and C. Dunnick, "The epidemiology of acne vulgaris in late adolescence," Adolesc. Health. Med. Ther., 2016.

[35] A. Smithard, C. Glazebrook, and H. C. Williams, "Acne prevalence, knowledge about acne and psychological morbidity in mid-adolescence: A community-based study," Br. J. Dermatol., 2001.

[36] S. Fitz-Gibbon et al., "Propionibacterium acnes strain populations in the human skin microbiome associated with acne," J. Invest. Dermatol., 2013.

[37] S. A. Corbet et al., "Native or exotic? Double or single? Evaluating plants for pollinatorfriendly gardens," Ann. Bot., 2001.

[38] J. A. Halvorsen, R. S. Stern, F. Dalgard, M. Thoresen, E. Bjertness, and L. Lien, "Suicidal ideation, mental health problems, and social impairment are increased in adolescents with acne: A population-based study," J. Invest. Dermatol., 2011.

[39] H. J. Ensikat, P. Ditsche-Kuru, C. Neinhuis, and W. Barthlott, "Superhydrophobicity in perfection: The outstanding properties of the lotus leaf," Beilstein J. Nanotechnol., 2011.

[40] A. Marmur, "The lotus effect:Superhydrophobicity and metastability," Langmuir, 2004.

[41] S. S. Latthe, C. Terashima, K. Nakata, and A. Fujishima, "Superhydrophobic surfaces developed by mimicking hierarchical surface morphology of lotus leaf," Molecules. 2014.

[42] S. Sato et al., "Genome structure of the legume, Lotus japonicus," DNA Res., 2008. 
[43] J. P. Gomes, A. Watad, and Y. Shoenfeld, "Nicotine and autoimmunity: The lotus' flower in tobacco," Pharmacological Research. 2018.

[44] M. Q. Man et al., "Variation of skin surface pH, sebum content and stratum corneum hydration with age and gender in a large chinese population," Skin Pharmacol. Physiol., 2009.

[45] M. Lovászi, A. Szegedi, C. C. Zouboulis, and D. Törőcsik, "Sebaceous-immunobiology is orchestrated by sebum lipids," Dermatoendocrinol., 2017.

[46] S. Mukherjee et al., "Sebum and Hydration Levels in Specific Regions of Human Face Significantly Predict the Nature and Diversity of Facial Skin Microbiome," Sci. Rep., 2016.

[47] "Molyrose | Advanced Acne Clearing Solutions," Molyrose. https://www.molyrose.com/ 10Jan-2020.

[48] A. C. Perkins, C. E. Cheng, G. G. Hillebrand, K. Miyamoto, and A. B. Kimball, "Comparison of the epidemiology of acne vulgaris among Caucasian, Asian, Continental Indian and African American women," J. Eur. Acad. Dermatology Venereol., 2011.

[49] A. Pappas, S. Johnsen, J.-C. Liu, and M. Eisinger, "Sebum analysis of individuals with and without acne.," Dermatoendocrinol., 2009. 